\title{
Petrochronology and thermochronology of apatite
}

\author{
D.M. HHEW $^{1}$, R.A. SPIKINGS ${ }^{2}$, C. MARK ${ }^{3}$, \\ G. O'Sullivan ${ }^{3}$, I.A. Henrichs ${ }^{1}$, C. AnsBerque ${ }^{1}$
}

${ }^{1}$ Department of Geology, Trinity College Dublin, Ireland

${ }^{2}$ Department of Earth Sciences, University of Geneva, Switzerland

${ }^{3}$ School of Earth Sciences, University College Dublin, Ireland

Apatite is often used as a low-T thermochronometer, with the apatite fission-track (AFT; $\left.60-110^{\circ} \mathrm{C}\right)$ and $(\mathrm{U}-\mathrm{Th}) / \mathrm{He}(40-$ $80^{\circ} \mathrm{C}$ ) methods popular tools for studying upper crustal processes. The higher temperature sensitivity of the U-Pb apatite system $\left(350-550^{\circ} \mathrm{C}\right)$ makes it a powerful tool to study the thermal histories of the deeper crust. Recent studies exploit diffusive $\mathrm{Pb}$ loss from apatite crystals to generate $\mathrm{t}-\mathrm{T}$ paths between $\sim 350-550{ }^{\circ} \mathrm{C}$, by comparing apatite U-Pb IDTIMS dates with grain size or by LA-MC-ICP-MS age depth profiling / traverses of apatite crystals ${ }^{1,2}$. In most cases, the effective diffusion domain is likely the entire crystal.

Apatite has both advantages and limitations as a thermochronometer/petrochronometer compared to other mineral dating systems. Its trace element chemistry is both highly diverse and rock-type specific, permitting discrimination of igneous (including various sub-categories), authigenic, and low- $v s$ high-grade metamorphic apatite ${ }^{3}$. This enables reprecipitated domains to be identified geochemically and linked with petrographic observations, such as low-grade apatite overgrowths on detrital igneous apatite cores in metasedimentary rocks ${ }^{4}$. Apatite recrystallization is controlled by fluid-interaction ${ }^{5}$, which is likely orders of magnitude faster than volume $\mathrm{Pb}$ diffusion ${ }^{6}$ and may dominate age spectra in "wet" rocks such as metapelites, while $\mathrm{Pb}$-diffusion may dominate in dehydrated lithologies.

Limitations include low $\mathrm{U}$ contents and significant initial $\mathrm{Pb}$, resulting in low $\mathrm{U} / \mathrm{Pb}^{*}$ ratios. In particular, low-grade metamorphic apatite yields low U contents $\left(<<1 \mathrm{ppm}^{3,4}\right)$, making it a less useful chronometer in young orogenic belts. Apatite U-Pb thermochronology studies ${ }^{1,2}$ will thus be heavily weighted towards high-U-apatite bearing ${ }^{3}$ lithologies (e.g. Stype granites). An appropriate choice of initial $\mathrm{Pb}$ composition is critical in all $\mathrm{U}-\mathrm{Pb}$ thermochronology studies. $\mathrm{U}$ zoning remains an issue for inverse modelling of singlegrain ID-TIMS dates ${ }^{4}$, and LA-MC-ICP-MS age traverses need to be integrated with $\mathrm{U}$ zoning information.

1) Cochrane et al., 2014, GCA. 2) Paul et al., 2019, GCA.

3) O'Sullivan et al., 2020, ESR. 4) Henrichs et al., 2019, G3.

5) Harlov et al., 2005, CMP. 6) Villa, 2016, Chem Geol. 